\title{
A case report of successfully treated nephrotic syndrome after renal angioplasty
}

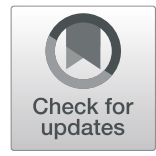

Hee Jung Park , Ha Nee Jang ${ }^{1}$, Hyun Seop Cho ${ }^{1,2,3}$, Se-Ho Chang ${ }^{1,2,3}$ and Hyun-Jung Kim ${ }^{1,2,3^{*}}$ (D)

\begin{abstract}
Background: The standard treatment of renovascular hypertension accompanying renal artery stenosis (RAS) consists of angioplasty and administration of antihypertensive medication. Although nephrotic syndrome (NS) has been reported to be associated with RAS, the development of NS after revascularization of RAS is extremely rare.

Case presentation: A 48-year-old man presented with uncontrolled hypertension and azotemia. The right kidney was atrophic, and RAS of the left kidney was suspected based on a post-captopril DTPA scan. His blood pressure stabilized after renal angioplasty; however, he complained of edema after 1 week. NS developed and was diagnosed as focal segmental glomerulosclerosis (FSGS) based on renal biopsy. He received an angiotensin receptor blocker. Proteinuria resolved after 1 year.
\end{abstract}

Conclusions: FSGS rarely develops after angioplasty of renal artery stenosis. This is the first report of successful treatment of this condition using an angiotensin receptor blocker during 1-year follow-up.

Keywords: Renal angioplasty, Focal segmental glomerulosclerosis, Nephrotic syndrome, Renal artery stenosis

\section{Background}

Renal artery stenosis (RAS) is defined as a narrowing of one or both renal arteries or their branches and is a cause of renovascular hypertension [1]. Proteinuria can occur in patients with RAS, decreasing after angioplasty [2-4]. Nephrotic-range proteinuria in patients with RAS is uncommon, with most of these patients presenting with focal segmental glomerulosclerosis (FSGS) [5-9], defined as segmental glomerular scars involving some but not all glomeruli. Clinically, FSGS most frequently manifests as proteinuria and is present in up to onethird of adults with nephrotic syndrome (NS) [10]. However, nephrotic-range proteinuria has also been reported after angioplasty for RAS [11, 12], with FSGS occurring in the ipsilateral kidney after angioplasty. This report describes a patient who developed FSGS after renal angioplasty of a single functional kidney with RAS. This is the first report of successful treatment of this

\footnotetext{
*Correspondence: kimhjyh@naver.com

${ }^{1}$ Division of Nephrology, Department of Internal Medicine, Gyeongsang

National University Hospital, Jinju, South Korea

${ }^{2}$ Department of Internal Medicine, College of Medicine, Gyeongsang

National University, Jinju, South Korea

Full list of author information is available at the end of the article
}

condition using an angiotensin receptor blocker (ARB) during 1-year follow-up.

\section{Case presentation}

A 48-year-old man was referred to our hospital for evaluation of azotemia and uncontrolled blood pressure. Ten years earlier, he had been diagnosed with an intracerebral hemorrhage and underwent stereotactic hematoma aspiration. Due to uncontrolled hypertension at that time, he was evaluated for secondary hypertension at admission; however, no specific findings were observed on a captopril renal scan. Since then, he had been prescribed antihypertensive drugs by a private clinic.

At his first visit to our hospital for uncontrolled hypertension, his blood pressure was 160/90 mmHg despite triple therapy with amlodipine, carvedilol, and hydrochlorothiazide. His blood urea nitrogen concentration was $23.7 \mathrm{mg} / \mathrm{dl}$ (reference, $6.0-20.0 \mathrm{mg} / \mathrm{dl}$ ), his serum creatinine $(\mathrm{sCr})$ concentration was $1.45 \mathrm{mg} / \mathrm{dl}$ (reference, 0.6-1.2 $\mathrm{mg} / \mathrm{dl}$ ), and his estimated glomerular filtration rate (eGFR) using the CKD-EPI equation was $57 \mathrm{ml} /$ $\mathrm{min} / 1.73 \mathrm{~m}^{2}$. His serum total protein concentration was $7.4 \mathrm{~g} / \mathrm{dl}$, his serum albumin concentration was $4.5 \mathrm{~g} / \mathrm{dl}$ (reference, 3.5-5.2 g/dl), his total cholesterol concentration was $292 \mathrm{mg} / \mathrm{dl}$ (reference, 120-220 mg/dl), his low-

(c) The Author(s). 2019 Open Access This article is distributed under the terms of the Creative Commons Attribution 4.0 International License (http://creativecommons.org/licenses/by/4.0/), which permits unrestricted use, distribution, and reproduction in any medium, provided you give appropriate credit to the original author(s) and the source, provide a link to the Creative Commons license, and indicate if changes were made. The Creative Commons Public Domain Dedication waiver (http://creativecommons.org/publicdomain/zero/1.0/) applies to the data made available in this article, unless otherwise stated. 
density lipoprotein-cholesterol concentration was 195 $\mathrm{mg} / \mathrm{dl}$ (reference, $0-130 \mathrm{mg} / \mathrm{dl}$ ), his triglyceride concentration was $73 \mathrm{mg} / \mathrm{dl}$ (reference, $0-200 \mathrm{mg} / \mathrm{dl}$ ), his plasma renin activity (PRA) was $19.32 \mathrm{ng} / \mathrm{ml} / \mathrm{hr}$. (reference: supine, $0.32-1.84 \mathrm{ng} / \mathrm{ml} / \mathrm{hr}$; upright, $0.60-4.18 \mathrm{ng} /$ $\mathrm{ml} / \mathrm{hr}$ ), and his spot urine protein-to-Cr ratio (uPCR) was $0.4 \mathrm{~g} / \mathrm{g}$ without hematuria.

A renal ultrasonogram revealed that his right and left kidneys measured 6.3 and $10.3 \mathrm{~cm}$, respectively. Compared with a basal scan, a post-captopril DTPA renogram showed that the eGFR was $>10 \%$ lower in his left kidney, whereas his right kidney was non-functional (Fig. 1). A renal arteriogram showed $80 \%$ stenosis of his left renal artery, into which a stent was successfully inserted (Fig. 2), whereas his right kidney was faintly visible through collaterals. Four weeks after the procedure, the patient had developed marked generalized pitting edema compatible with NS, as shown by a uPCR of $11.6 \mathrm{~g} / \mathrm{g}$, and dyslipidemia. His PRA was $60.60 \mathrm{mg} / \mathrm{dl} /$ hr. at this time. Serological evaluation showed that he was negative for antibodies against immunoglobulins, complement, and hepatitis B and C viruses, as well as for antinuclear antibody. A biopsy of his left kidney resulted in a diagnosis of FSGS (Fig. 3). The patient was prescribed daily doses of the ARB candesartan, which reduced his uPCR to $2.2 \mathrm{mg} / \mathrm{mg}$ and his sCr to $1.30 \mathrm{mg} / \mathrm{dl}$ after 9 weeks. After 1 year, he recovered to his previous proteinuria range, and renal Doppler ultrasonography showed that his left renal artery was intact.

\section{Discussion and conclusions}

Nephrotic-range proteinuria ( $>3.5 \mathrm{~g} /$ day) is rare, but can occur in patients with renovascular hypertension and usually decreases after angioplasty [2]. Unilateral RAS is reportedly associated with NS, diagnosed as FSGS in the contralateral kidney. The mechanisms underlying the development of secondary FSGS in patients with RAS and renovascular hypertension include glomerular hypertension and hyperfiltration, activation of the renin-angiotensin II-aldosterone system by a high angiotensin II level, and injury of glomerular endothelial cells $[6,8]$. Proteinuria dramatically improves following medical therapy or revascularization in most cases. However, Bhardwaj et al. suggested that immune-mediated injury, not a hemodynamic factor, is involved in development of this condition and reported that NS resolves after steroid therapy [13].

By contrast, reports have described increasing proteinuria after revascularization in patients with RAS. We identified three cases with NS after angioplasty. A literature search identified two patients similar to ours with FSGS in the ipsilateral kidney following revascularization of a single functioning kidney [11, 12]. These patients developed nephrotic-range proteinuria 2-4 weeks after angioplasty and showed hyperreninemia. One patient refused additional workup, and the other showed increased proteinuria after ACE inhibitor treatment was terminated due to renal function deterioration. Both patients died within 1 year. But, NS in our patient was resolved and he maintains stable CKD stage G3aA2 after

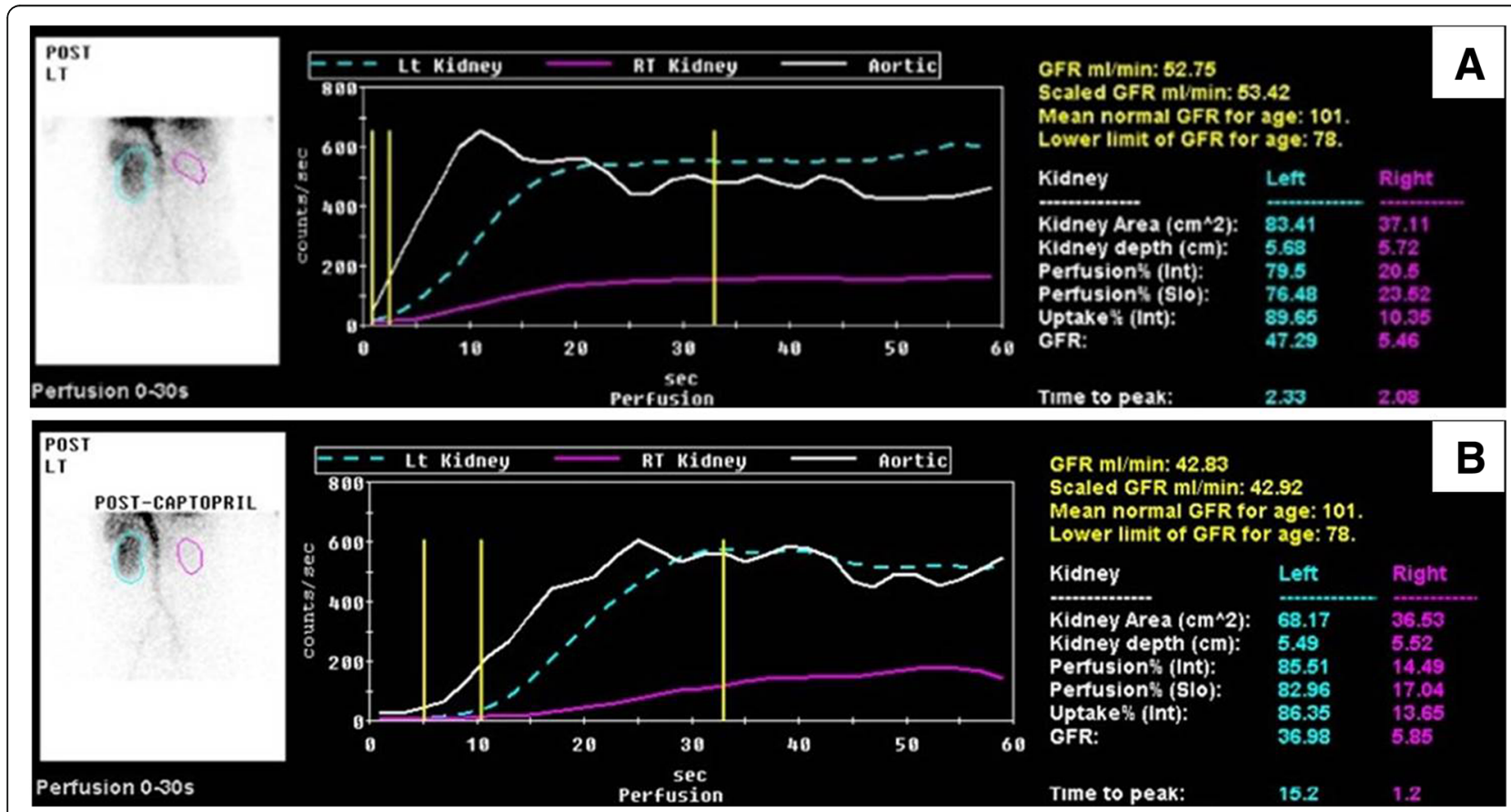

Fig. 1 a Basal and $\mathbf{b}$ post-captopril DTPA renograms. A comparison showed that the eGFR was reduced $>10 \%$ in the left kidney, whereas the right kidney was non-functional 

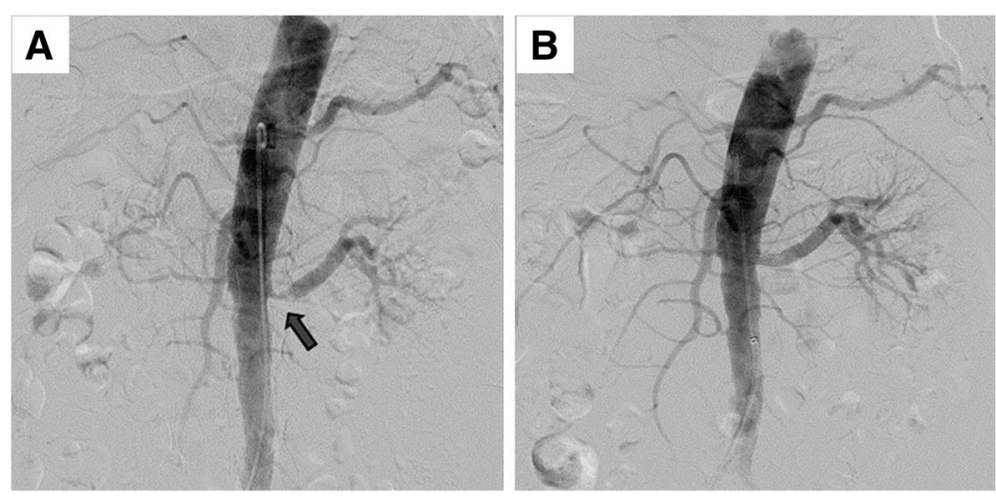

Fig. 2 a Renal artery CT angiogram showing severe stenosis of the left renal artery at its site of origin (80\%, arrows). b Successful insertion of a stent into the left renal artery

renal angioplasty and treatment with an ARB for 1 year (Table 1). Another patient was diagnosed with RAS due to fibromuscular dysplasia and developed nephroticrange proteinuria 2 days after angioplasty; however, NS spontaneously resolved within 1 week without any treatment [14].

Several hypotheses may account for FSGS after angioplasty in this patient. First, in the presence of RAS, an ischemic change may be induced from the renal artery stenosis and the number of functional nephrons may be reduced, with hyperfiltration of the remnant functional nephrons induced by hemodynamic changes causing secondary FSGS without proteinuria for a long time before angioplasy $[3,15,16]$. Alternatively, a timely restoration of blood flow may be essential to salvage the ischemic renal injury. However, abrupt hyperfiltration injury due to reperfusion after angioplasty can paradoxically cause proteinuria via the damage to podocytes in the remnant ischemic tissue [17]. On the other hand, RAS can protect some glomerular injury. Bonsib et al. showed asymmetrical glomerular injury in a patient with unilateral RAS and glomerulonephritis. This protection from hyperfiltration and glomerular damage in the post-stenotic kidney can be removed by angioplasty and develop the nephrotic synrome [18]. These hemodynamic factors may cause FSGS because elevated intraglomerular hydrostatic pressure and over-distension of the glomerular capillary loop may injure podocytes.

The two-kidney one-clip (2K1C) model results in unilateral RAS. Perfusion is reduced in the stenotic kidney, and the renin-angiotensin system is activated, which stimulates the sympathetic nervous system and promotes hypertension. Perfusion is maintained in the contralateral non-stenotic kidney, and sodium and water are excreted via pressure natriuresis, with the overall plasma volume remaining normal. By contrast, the twokidney two-clip $(2 \mathrm{~K} 2 \mathrm{C})$ model of bilateral RAS and the one-kidney one-clip $(1 \mathrm{~K} 1 \mathrm{C})$ model with a single functioning kidney, both of which lack a normal contralateral kidney, experience sodium retention, with the renin concentration being normal or somewhat reduced $[19,20]$. The findings in our patient are compatible with the 2K2C model, with PRA increasing after angioplasty. Proteinuria resolved following ACE inhibitor treatment. The

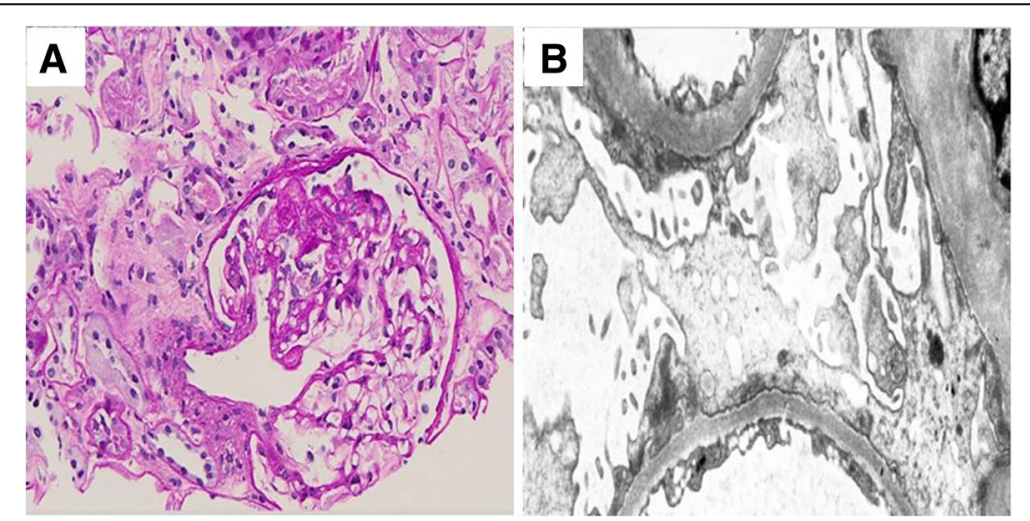

Fig. 3 a Biopsy of the left kidney showing a glomerulus with segmental sclerosis (PAS, $\times 200)$. b Electron photomicrograph showing focal areas of mild epithelial foot process fusion; electron-dense deposits were not observed 
Table 1 Clinical manifestations in three patients with FSGS after renal angioplasty

\begin{tabular}{|c|c|c|c|}
\hline & Kanagasundaram et al. [11] & Almirall et al. [12] & This patient \\
\hline Age (years) & 65 & 72 & 48 \\
\hline Sex & Female & Male & Male \\
\hline Blood pressure (mmHg) & $220 / 120$ & $240 / 120$ & $160 / 90$ \\
\hline Anti-HTN drugs & $\begin{array}{l}\text { Amlodipine, doxazocin, } \\
\text { furosemide }\end{array}$ & $\begin{array}{l}\text { Amlodipine, lisinopril, } \\
\text { hydrochlorothiazide }\end{array}$ & $\begin{array}{l}\text { Carvedilol, } \\
\text { hydrochlorothiazide }\end{array}$ \\
\hline Serum creatinine (mg/dl) & 2.07 & 1.90 & 1.42 \\
\hline Proteinuria before angioplasty & Normal & 100 mg/day & $0.4 \mathrm{~g} / \mathrm{g}$ \\
\hline \multicolumn{4}{|l|}{ Renal angiography } \\
\hline Degree of RAS (\%) & 95 & 80 & 80 \\
\hline Opposite kidney & Non-perfused & Complete occlusion & Non-functional \\
\hline Onset of nephrotic syndrome after angioplasty (weeks) & 2 & 3 & 4 \\
\hline Proteinuria after angioplasty & 5.9 g/day & 13 g/day & $11.6 \mathrm{~g} / \mathrm{g}$ \\
\hline PRA before angioplasty & - & - & $19.32 \mathrm{ng} / \mathrm{ml} / \mathrm{hr}$ \\
\hline PRA after angioplasty (reference) & $\begin{array}{l}11.6 \mathrm{pmol} / \mathrm{ml} / \mathrm{hr} \\
(2.8-4.5)\end{array}$ & $669 \mathrm{pg} / \mathrm{ml}(<300)$ & $\begin{array}{l}60.6 \mathrm{mg} / \mathrm{ml} / \mathrm{hr} \\
(1.31-3.95)\end{array}$ \\
\hline Management & ACEl & & ARB \\
\hline Change in proteinuria & 3.1 g/day (2 weeks with ACEI) & 16 g/day & $2.2 \mathrm{~g} / \mathrm{g}$ (9 weeks with ARB) \\
\hline Follow-up & $\begin{array}{l}\text { Proteinuria } 6.5 \mathrm{~g} / \text { day } \\
\text { (after ACEI withdrawal) }\end{array}$ & $\begin{array}{l}\text { Death due to } \mathrm{ICH} \text { at } \\
4 \text { months after angioplasty }\end{array}$ & $\begin{array}{l}\text { UPCR } 0.4 \mathrm{~g} / \mathrm{g} \\
\text { (1 year with ARB) }\end{array}$ \\
\hline
\end{tabular}

Abbreviations: $A C E I$ angiotensin-converting enzyme inhibitor, $A R B$ angiotensin receptor blocker, $H T N$ hypertension, ICH intracranial hemorrhage, $P R A$ plasma renin activity, RAS renal artery stenosis, uPCR urine protein-to-creatinine ratio

patient's persistent hyperreninemia and response to reninangiotensin-aldosterone system inhibition indicate that a hemodynamic factor was involved in proteinuria. His hyperreninemia may be related to renin production by remnant tissue of the non-functioning contralateral kidney.

Massive proteinuria after successful angioplasty is indicative of acute changes in hemodynamic factors. RAS may have been present in a single kidney, resulting in subclinical FSGS. Acute hyperfiltration upon reperfusion after angioplasty may have induced release of proinflammatory cytokines and oxidative stress from activated the renin-angiotensin-aldosterone system, leading to NS. These effects may be controlled by blocking the renin-angiotensin system, suggesting the need for periodic clinical follow-up. Large hemodynamic changes over a short period of time before and after angioplasty were speculated to be the cause of FSGS, although we report here development of proteinuria secondary to FSGS post revascularization, we can only speculate regarding the precise mechanism and this will need further investigation.

This report describes a patient with a single functional kidney and RAS who developed FSGS after renal angioplasty. Proteinuria in this patient was resolved following treatment with an ARB for 1 year. Changes in proteinuria should be evaluated in patients with renovascular hypertension before and after angioplasty. These patients may benefit from treatment with renin-angiotensin-aldosterone system inhibitors.

\section{Abbreviations}

ARB: Angiotensin receptor blocker; eGFR: Estimated glomerular filtration rate; FSGS: Focal segmental glomerulosclerosis; NS: Nephrotic syndrome;

PRA: Plasma renin activity; RAS: Renal artery stenosis; sCr: Serum creatinine; UPCR: Urine protein-to-creatinine ratio

\section{Acknowledgments \\ The authors thank the patient for his support.}

\section{Authors' contributions}

HJP and HJK collected data and wrote the manuscript. HNJ, HSC, and SHC critically reviewed the paper and contributed to the discussion. All authors reviewed the final manuscript and approved it for submission.

Funding

None.

Availability of data and materials

The relevant clinical details are presented in this report.

Ethics approval and consent to participate

Ethical approval was not sought for the publication of this case report.

\section{Consent for publication}

The patient provided informed written consent for publication of his clinical details and radiological images while maintaining his anonymity.

\section{Competing interests}

The authors declare that they have no competing interests.

\section{Author details}

'Division of Nephrology, Department of Internal Medicine, Gyeongsang National University Hospital, Jinju, South Korea. ${ }^{2}$ Department of Internal Medicine, College of Medicine, Gyeongsang National University, Jinju, South Korea. ${ }^{3}$ Institute of Health Sciences, Gyeongsang National University, Jinju, South Korea. 
Received: 19 November 2018 Accepted: 29 July 2019

Published online: 06 August 2019

\section{References}

1. Lao D, Parasher PS, Cho KC, Yeghiazarians Y. Atherosclerotic renal artery stenosis--diagnosis and treatment. Mayo Clin Proc. 2011;86(7):649-57.

2. La Batide-Alanore A, Azizi M, Froissart M, Raynaud A, Plouin PF. Split renal function outcome after renal angioplasty in patients with unilateral renal artery stenosis. J Am Soc Nephrol. 2001;12(6):1235-41.

3. Sato H, Saito T, Kasai Y, Abe K, Yoshinaga K. Massive proteinuria due to renal artery stenosis. Nephron. 1989;51(1):136-7.

4. Hariharan S, Pandey AP, Jacob CK, Shastry JC, Kirubakaran MG. Nephroticrange proteinuria with renal artery stenosis: its reversal after transluminal angioplasty. Nephron. 1987:47(1):77.

5. Thadhani R, Pascual M, Nickeleit V, Tolkoff-Rubin N, Colvin R. Preliminary description of focal segmental glomerulosclerosis in patients with renovascular disease. Lancet. 1996;347(8996):231-3.

6. Bhowmik D, Dash SC, Jain D, Agarwal SK, Tiwari SC, Dinda AK. Renal artery stenosis and focal segmental glomerulosclerosis in the contralateral kidney. Nephrol Dial Transplant. 1998;13(6):1562-4.

7. Hong SJKD, Ku CR, Lee HS, Choi KH, Lee HY, Han DS, Jeong HJ, Kim BS. A case of unilateral renal artery stenosis with contra-lateral focal segmental glomerulosclerosis in a chronic kidney disease patient. Korean J Nephrol. 2007;26(2):264-8.

8. Alkhunaizi AM, Chapman A. Renal artery stenosis and unilateral focal and segmental glomerulosclerosis. Am J Kidney Dis. 1997;29(6):936-41.

9. Alchi B, Shirasaki A, Narita I, Nishi S, Ueno M, Saeki T, Miyamura S, Gejyo F. Renovascular hypertension: a unique cause of unilateral focal segmental glomerulosclerosis. Hypertens Res. 2006;29(3):203-7.

10. Lewis JBNE. Glomerular diseases. In: Kasper DLFA, Hauser SL, Longo DL, Jameson JL, Loscalzo J, editors. Harrison's principles of internal medicine, vol. 2. 19th ed. McGraw-Hill: the United States; 2015. p. 1842.

11. Kanagasundaram NS, Allan BJ, Kessel D, Newstead CG, Worth DP. Nephrotic syndrome after successful renal angioplasty. Nephrol Dial Transplant. 1998; 13(3):767-8.

12. Almirall J, Mendez I, Comet R, Andreu X. Nephrotic syndrome after renal percutaneous transluminal angioplasty. Nephrol Dial Transplant. 2000;15(10): $1696-9$.

13. Bhardwaj R, Dosani I, Clark BA. Steroid-responsive nephrotic syndrome and bilateral renal artery stenosis: a possible role for angiotensin-mediated podocyte injury. Case Rep Nephrol Urol. 2012;2(1):59-64.

14. Heran MK, Sangha BS, White C. Renal hyperperfusion injury resulting in transient proteinuria post renal artery angioplasty for fibromuscular dysplasia. Pediatr Radiol. 2012;42(4):491-4.

15. Meyrier A, Hill GS, Simon P. Ischemic renal diseases: new insights into old entities. Kidney Int. 1998;54(1):2-13.

16. Al-Suraih M, Grande JP. Management of renal artery stenosis: what does the experimental evidence tell us. World J Cardiol. 2014;6(8):855-60

17. van Mook WN, Rennenberg RJ, Schurink GW, van Oostenbrugge RJ, Mess WH, Hofman PA, de Leeuw PW. Cerebral hyperperfusion syndrome. Lancet Neurol. 2005;4(12):877-88.

18. Bonsib SM, Goeken JA. Renal artery stenosis modifies glomerular injury in antineutrophil cytoplasmic antibody-associated disease. Am J Kidney Dis. 1992;20(5):509-12.

19. Goldblatt H, Lynch J, Hanzal RF, Summerville WW. Studies on experimental hypertension : I. the production of persistent elevation of systolic blood pressure by means of renal ischemia. J Exp Med. 1934;59(3):347-79.

20. BM B. Brenner and Rector's the kidney, vol II. Renovascular hypertension and ischemic nephropathy, vol II, 7th edn. Saunders: The United States; 2004.

\section{Publisher's Note}

Springer Nature remains neutral with regard to jurisdictional claims in published maps and institutional affiliations.

Ready to submit your research? Choose BMC and benefit from:

- fast, convenient online submission

- thorough peer review by experienced researchers in your field

- rapid publication on acceptance

- support for research data, including large and complex data types

- gold Open Access which fosters wider collaboration and increased citations

- maximum visibility for your research: over $100 \mathrm{M}$ website views per year

At $\mathrm{BMC}$, research is always in progress.

Learn more biomedcentral.com/submissions 